Journal of Industrial Relations $0(0) \mathrm{I}-20$

\title{
Advancing understanding on industrial relations in multinational companies: Key research challenges and the INTREPID contribution
}

\section{Patrick Gunnigle}

University of Limerick, Ireland and Rhodes University,

South Africa

\section{Valeria Pulignano}

Katholieke Universiteit - Leuven, Belgium

\section{Tony Edwards}

King's College, London, UK

\section{María J Belizón}

University of Limerick, Ireland

\section{Steen Navrbjerg}

University of Copenhagen, Denmark

\section{Karen M Olsen}

Norwegian School of Economics, Norway

\section{Lourdes Susaeta}

University of Navarra, Spain

\begin{abstract}
This paper has three principal aims. It firstly provides some theoretical background on the key current research issues and challenges in regard to industrial relations in multinational companies. It then presents a concise review of scholarship to date on industrial relations in multinational companies using INTREPID (Investigation of Transnationals'
\end{abstract}

Corresponding author:

Patrick Gunnigle, Kemmy Business School, University of Limerick, Limerick, Ireland.

Email: Patrick.gunnigle@ul.ie 
Employment Practices: an International Database) data. Finally, the paper identifies some of the main industrial relations issues that remain to be addressed, in effect charting a form of research agenda for future work using the INTREPID data, with particular focus on the potential contribution from 'late joiners' to the INTREPID project.

\section{Keywords}

Autonomy, control, employee voice, industrial relations, institutionalism, multinational companies, trade unions

\section{Introduction}

The objectives of this paper are threefold. We initially review some of the key current debates regarding industrial relations in multinational companies (MNCs). We then consider the contribution of the so-called INTREPID (Investigation of Transnationals' Employment Practices: an International Database $^{1}$ ) study to these debates. INTREPID comprises a network of international scholars involved in coordinated surveys of employment practice in MNCs in different national contexts with the objective of providing an accurate and representative picture of employment practices in MNCs. The paper concludes by identifying a number of industrial relations issues that remain to be addressed or further investigated, thus charting a research agenda for future work using the INTREPID database with particular focus on the potential contribution from 'second wave' countries, namely, Australia, Argentina, Belgium, Mexico and the Nordic area (Denmark and Norway).

\section{Industrial relations in MNCs}

Aside from a conviction that home and host-country factors influence management practice in industrial relations within MNC subsidiaries, recent literature - including some work based on the INTREPID project - identifies the influence of organisational and structural characteristics of MNCs themselves in impacting on management practice, including that affecting industrial relations. This reinforces the need to look beyond macro-institutional effects alone and include micro-organisational and MNC characteristics to develop an in-depth and comprehensive understanding of the factors impacting on industrial relations practice and subsidiary level autonomy over industrial relations within MNCs. Furthermore, although qualitative research has been developed around management approaches to industrial relations on the one hand, and employee representatives' perception of those practices on the other (cf. Almond and Ferner, 2006; Marginson et al., 2004; Waddington, 2010), in-depth quantitative analysis of factors shaping variation across subsidiary level is, to date, quite limited. The INTREPID database offers a unique opportunity to address these aspects. By drawing on an extensive international database, compiled from parallel 
surveys of employment practice in the operations of MNCs in 10 countries, it offers the basis for a robust analysis and understanding of industrial relations and its determinants within MNC subsidiaries across borders.

Two contrasting logics characterise much of the extant literature on MNCs and industrial relations. On the one hand, a long research tradition suggests that trade unions, employee representation structures and conventions are deeply embedded in national political economies, and that their institutions are so powerful that MNCs are forced to adapt to local traditions (e.g. collective bargaining, interaction with works councils) despite corporate preference to act otherwise for reasons related to perceived competitive advantage (Taylor et al., 1996; Whitley, 2001). On the other hand, the countervailing logic is that MNCs operate in a manner which is 'exogenous to national path dependencies' (Lamare et al., 2013: 695) and seek to deploy practices developed in different national contexts and/or utilise approaches which dilute the impact of local institutional pressures. Some empirical studies have shown how US MNCs in coordinated market economies (CMEs) manage to substantially insulate themselves from the influence of trade unions and sectoral bargaining (e.g. Royle, 1998, 2000). This suggests that MNCs are increasingly seeking to adapt bargaining processes and structures to their own needs and to consider national and sectoral collective bargaining as less relevant to their own employment practices. Furthermore, they may increasingly compare themselves with other subsidiaries of their own company in other countries or in - domestic or foreign - competitors (Arrowsmith and Marginson, 2006). One possible scenario is that in countries with multi-employer bargaining traditions and strong trade unions, MNCs will push for greater decentralisation of collective bargaining and the concomitant freedom to negotiate their own employment practices with local unions, independently of national and sectoral dynamics, and to focus on the strengthening of their own competitiveness and adaptability (Marginson and Meardi, 2009).

Drawing from these various studies, which clearly illustrate some degree of autonomy in the way local (host country) management in MNC subsidiaries engage with local unions and their systems of collective representation, this paper highlights the need for additional empirical investigation of the factors influencing local management discretion over employee representation and engagement. Of particular interest is the interaction between macro-institutional (e.g. country-of-origin effects, host-country characteristics) and organisational and structural firm-level factors (e.g. international human resource management (HRM) structure, management organisation, ownership and demographic factors). Specifically, we are interested in understanding how these two groups of features influence patterns of employee representation and the extent and form of engagement by local management in industrial relations in MNC subsidiaries.

Much of extant literature on industrial relations in MNCs has focused on employee voice (cf. Boxall and Purcell, 2003). Lavelle et al. (2010: 396) define employee voice as 'any type of mechanisms, structure or practice, which provides an employee with an opportunity to express an opinion or participate in decisionmaking within their organization'. Employee voice is usually operationalised into 
two broad categories, namely, direct voice and indirect voice. Direct voice is described as any communication mechanism acting as a vehicle for employees to improve their direct involvement in management decision making. This classification refers mainly to participation, consultation and information sharing. Indirect voice encompasses any mechanisms that provide employees with the channel for expressing their views via 'some form of collective employee representation such as trade unions or non-union structures of collective representation (e.g. via consultative committees or work councils)' (Lavelle et al., 2010: 396). Since Freeman and Medoff (1984) profiled trade unions as key actors in the sphere of employee voice, we find a lack of consensus on this theme. Important manifestations of a shift in focus from trade unions and collective bargaining to other forms of employee voice include the progressive decline in trade union density in countries with strong trade union traditions and increased union avoidance, often based on the principles of the welfare capitalism as developed in the US and often practised by US MNCs abroad (Jacoby, 1997). Crucial questions remain as to the relative influence of macro- and micro-level effects on approaches to employee voice in MNC subsidiaries abroad.

\section{Institutionalism and MNCs}

Our starting point in investigating industrial relations within MNCs is a comparative institutionalism perspective which acknowledges that competitiveness in the international economic system is compatible with a wide range of national-institutional arrangements. Specifically, industrial and employment studies have centred on two contrasting propositions while examining the influence MNCs possess in shaping employment practices. Scholars drawing from the salience of different 'national business systems' (Whitley, 1999) point to strong national effects on local employment policies and practices in MNCs. This thereby leads to systemic differences in the way national business systems organise their economic activity through the mechanisms governing the operation of capital, labour and product markets and their subsequent impact on MNCs' behaviour (Ferner et al., 2005). Thus, the primary assumption of the institutionalist approach is that MNCs will be influenced in their international operations by the structures, operating models, and patterns of thoughts and behaviour they have developed in response to the business context in which they originate (Whitley, 2001). Specifically, it is claimed that country of origin effects influence MNCs' attitudes and approaches to unions and collective employee representation (Ferner and Quintanilla, 2008). Accordingly, for example, German-owned multinationals tend to exhibit strong firm-based indirect representative forms of employee voice, contrasting with USowned MNCs which appear to prefer direct engagement with employees (Ferner and Varul, 1999). Specifically, studies of MNCs in Ireland suggest that many US MNCs engage in union avoidance in order to avoid having to take part in collective bargaining, among other reasons (Gunnigle, 1995; Gunnigle et al., 2005). 
Nevertheless, some literature has noted that globalisation processes do not have simple homogenising effects: rather, they are reshaped, resisted and redeployed by the socially embedded processes of the host location, emphasising country of operation-level distinctiveness (Ferner and Quintanilla, 1998). More specifically, it is argued that country of operation effects influence the application of MNCs' employment policies and practices on the ground (Almond et al., 2005). In particular, these studies show that even when MNCs apply 'best' employment practices globally, local adaptation of these practices remains necessary. Since employee representation systems are deeply embedded in national institutional arrangements, it would be difficult for foreign MNCs to simply transfer home-country approaches into different national contexts. Rather, as some researchers argue, it seems more plausible that MNC subsidiaries adapt their practices to accommodate local context, including national legislation concerning collective bargaining, employee representation structures and social rights of information and consultation (Whitley, 2001). This work frequently draws a contrast between CMEs, which have higher levels of regulation and institutionalisation of employee representation structures and practices, and liberal market economies (LMEs), characterised by lower levels of regulation regarding employee representation and works councils' rights. The argument is that the range of employment practices open to firms is more controlled, and therefore restricted, in subsidiaries operating within CMEs than in LMEs.

\section{Beyond national institutionalism}

Home and host-country claims alone are insufficient to explain the development of industrial relations practices within MNCs, not least because of two main reasons reported in the literature. First, it is argued that, depending on the 'economic success' of the country of origin, MNCs from more 'successful' countries can more easily transfer their domestic management practices abroad (Royle, 2006). This 'economic dominance' effect may be particularly relevant for national economies which are highly reliant on foreign investment (Geary and Roche, 2001, Gunnigle et al., 2009). Second, a primary concern of contemporary institutional accounts concerns isomorphism or hybridisation at country level. Also known as 'dual institutional effect', this concerns the ways in which MNCs strategically adapt their practices to take advantage of institutional distance and abandon practices prevalent in their home countries. There is evidence, for example, of German MNCs opting to operate in environments where they are not subjected to codetermination and works councils (Meardi et al., 2009). On the other hand, MNCs from LMEs may more easily view their home practices as a source of competitive advantage and attempt to transfer these to host countries (Lamare et al., 2013). Thereby, the 'dual institutional effect' approach reflects the formal regulatory structures and the manner in which the socialisation process is framed by nation-specific formal and informal patterns of behaviour. 
From a comparative institutional perspective, social actors within MNCs are seen as operating between the competing institutional forces exerted by MNC head office at home (parent company) as it attempts to transfer policy to the subsidiary, and those forces exerted by the host institutional context within which the MNC operates. In addition, Whitley (1999) argues that firms within different host institutional contexts may demonstrate different ways of dealing with employment and industrial relations institutional structures, such as systems of employee representation and collective bargaining, which often go beyond the traditional institutional contrast between CMEs and LMEs. More specifically, MNCs' industrial relations practices may be influenced by the extent of organisational leeway enjoyed by local actors at subsidiary level. Hence, within the context of the home and host institutional factors, MNCs at local level develop their own strategy, using their discretion to pursue specific interests and locally negotiating in that respect. For example, Meardi et al. (2009) found that country of origin and country of operation effects partly explained the transfer of employment practices in US and German multinationals' subsidiaries in Central and Eastern European countries because of the 'contested' and 'contingent' nature of the process of transfer within MNCs. This is the case for different reasons. First of all, MNCs have to negotiate with powerful actors in the local environment, such as the unions and their existing structures of employee representation. Second, actors at different organisational levels may have different interests as well as different resources. From a power and interest perspective, the mechanisms through which local managers attempt to exercise their autonomy at the subsidiary level can be diverse and reflect their organisational interests and local power resources (Ferner et al., 2013). Sometimes local management can negotiate a path through various, sometimes contradictory, institutional pressures from the home and host environments. Power resources may derive from a subsidiary's success and consequent credibility within the wider firm and from the local actors' ability to exploit the local institutional context. By acting as interpreters of the possibilities and limits of the local institutional environment, subsidiary actors may lever considerable freedom of action for themselves in the face of institutional pressures from headquarters and from the institutional forces of the parent-country business system (Ferner et al., 2005). Williams and Geppert (2011) report that German management used the argument that works councils would not agree to certain measures in order to resist decisions made at corporate level while preserving their autonomy and engaging with works councils to 'fight for their plants'.

Hence, differential degrees of local management autonomy affect how industrial relations practices and policies are developed within MNCs. This is because macroinstitutional forces may be variably used by local actors at subsidiary level to shape industrial relations policy and practice within MNCs. This further denotes the need to attribute particular relevance to the level of discretion local MNC actors have in shaping particular employment practices and identify the main factors explaining it, and examine how they interact within MNCs. 


\section{The INTREPID contribution}

As noted earlier, INTREPID comprises a network of international scholars involved in parallel large scale surveys of employment practice in MNCs in different national contexts. The principal objective is to ensure an accurate, representative depiction of the activities of MNCs, especially in the areas of employment practice and industrial relations. The data collected are the outcome of the most representative comparative surveys of employment practice in MNCs located in the respective countries. The lack of representativeness in previous studies of MNCs has been noted by several observers over the years (Collinson and Rugman, 2010; Edwards et al., 2007; McDonnell et al., 2007) with disquiet expressed regarding sample bias. This particularly relates to concern that much of the MNC literature is dominated by over-sampling/reliance on data from a small cohort of large, well known (brand named) US-owned manufacturing companies, such as Intel, GE and Microsoft (Collinson and Rugman, 2010). This may also commonly lead to the exclusion of, or limited emphasis on, indigenous MNCs who are often major employers in their home country (McDonnell et al., 2014). In defining MNCs, the INTREPID methodology sought to address these shortfalls by initially distinguishing between foreign and domestic owned MNCs and then by establishing a size threshold as follows:

- Foreign-owned MNCs are wholly or majority foreign-owned organisations operating in the host country with 500 or more employees worldwide and 100 or more employed in their host-country operations.

- Domestic-owned MNCs are wholly or majority home country-owned organisations with 500 or more employees worldwide and at least 100 employed abroad.

The next phase involved identifying the relevant population of MNCs in each country. The compilation of an accurate and comprehensive listing of the population of MNCs proved to be a particularly painstaking task requiring a detailed review of various listings of MNCs provided by national agencies and organisations specialising in company databases. Full details on this process and our overall methodology are outlined in Edwards et al. (2013).

The third (fieldwork) phase required the completion of structured face to face interviews with the most senior HR director or manager able to answer for all of the operations in the relevant host country. ${ }^{2}$ Respondents were asked to report on various aspects of organisational structure/characteristics and also on five aspects of employment practice - the HR function, pay and performance management, employee representation and consultation, employee involvement and communication, and training, development and organisation learning. In investigating these areas, information was sought on employment practice relating to three specific groups of employees, namely the 'largest occupational group (LOG)', 'managers' and the 'key group' defined immediately below. This approach reflects the idea that 
different 'bundles' of employment/HR practices may be deployed among different categories of employees (Lepak and Snell, 1999).

- LOG: the largest non-managerial occupational group among the employees in the MNCs' operations in each country. For example, in a manufacturing business it might be semi-skilled operators or in an insurance company it might be call centre staff.

- Managers: employees who primarily manage the organisation or a department, subdivision, function or component of the organisation and whose main tasks consist of the direction and coordination of the functioning of the organisation. In other words, managers are those above the level of first-line supervision.

- Key group: those employees whom MNCs might identify as critical to the firm's organisational learning and core competence. These might be research staff, product designers, major account handlers, developers of new markets, etc.

Surveys were completed in the 'first wave' countries (Canada, Ireland, Spain and the UK) between 2006 and 2008. These are seen as the most representative and comprehensive investigations of employment practices in MNCs in their respective countries (Edwards et al., 2013). Equivalent surveys in the 'second wave' countries (Argentina, Australia, Belgium, Denmark, Mexico and Norway) were undertaken between 2010 and 2013. The INTREPID project thus provides a unique and distinctive resource of original data on which to base empirical investigation of the multifaceted dimensions surrounding multinational firms as powerful economic, financial and socio-political actors within the international economy.

Since completion of the first wave country surveys, a body of published work using INTREPID data has emerged. Not all of this has focused on industrial relations, though much has. Arguably, the most significant industrial relations contribution from first wave INTREPID data was captured in the special issue of Industrial and Labor Relations Review entitled 'Cross-National Perspectives on Multinational Companies and Employment Relations' (volume 66, number 3, 2013). In the following two sections, we review the published literature on INTREPID data to date and its contribution to enhancing our understanding of industrial relations in MNCs.

\section{Employee voice and MNCs}

Institutional (macro) level effects on employee voice. In line with our earlier discussion, much of the relevant published work has placed particular emphasis on how institutional context in the country of origin informs MNC approaches to employee voice (cf. Edwards et al., 2012; Gooderham et al., 2011; Gunnigle et al., 2009; Lavelle, 2008; Marginson et al., 2010, 2013; Minbaeva and Navrbjerg, 2011; Sablok et al., 2013). The use of direct and indirect employee voice along with the incidence of hybrid or dualistic systems has been investigated through an approach that uses, and seeks to go beyond, the 'varieties of capitalism' 
(VoC) lens (Lamare et al., 2013). To some extent, the evidence has corroborated some expectations that a $\mathrm{VoC}$ approach generates, such as the ingrained tendency of US MNCs for union avoidance and the use of direct mechanisms of employee voice in their Canadian, British and Irish subsidiaries. Similar findings were statistically supported by Lavelle et al. (2010) in their study of employee voice in MNCs with operations in Ireland. Lamare et al. (2013: 713), in exploring variations among MNCs based in Canada, Ireland and the United Kingdom, note that 'within LME host environments, US subsidiaries differ in terms of trade union status when compared against those from other home countries, particularly, CMEs'. They found that union presence in German, Nordic, British and other European-owned MNCs operating in the three LME nations studied was higher than the levels of unionisation in US MNCs.

However, some of the expectations generated by a $\mathrm{VoC}$ approach were not supported. For instance, Nordic and Japanese-owned MNCs, despite their origins in quite different forms of capitalism, were not significantly different from their US counterparts (Lamare et al., 2013; Marginson et al., 2010). Moreover, doublebreasting, defined as the simultaneous operation of unionised and non-unionised sites (Gunnigle et al., 2009), was found to be especially characteristic of Nordic and US-owned MNC subsidiaries despite the marked differences in the institutions of the countries of origin (Lamare et al., 2013). One interpretation of these findings is that they suggest that MNCs may be implementing employee voice arrangements similar to the 'dominant' group of US firms (Ferner and Varul, 1999). The idea that 'dominance' effects are evident in MNCs' approaches to employee voice appears to be particularly strong in countries that are heavily reliant on foreign direct investment (FDI) inflows. Lamare et al. (2013) highlight the particular case of US MNCs in Ireland, which account for over $60 \%$ of FDI. In line with this, high levels of union avoidance were reported among MNCs operating in Ireland due largely to the disproportionate number of US MNCs there but also possibly accentuated by Ireland's comparatively permissive industrial relations system. Union avoidance was especially evident in new sites opened by MNC subsidiaries (Lamare et al., 2013; Marginson et al., 2010). These scholars note that union avoidance in US MNCs does not only imply a growing presence of direct employee voice but also an increase of non-union employee representation structures such as work councils or consultative committees.

Organisational (micro) effects on employee voice. A longstanding focus on institutional context has traditionally characterised the literature on employee voice in $\mathrm{MNC}$ subsidiaries with the consequence that scholars have often relegated micro-level effects to the background. Often treated as control variables, the relevance of firmspecific characteristics is now gaining ground in explaining variation in industrial relations (Bechter et al., 2012; Marginson et al., 2010), and employee voice in particular (Edwards et al., 2012; Lamare et al., 2013; Lavelle et al., 2010; Marginson et al., 2010). INTREPID scholars have been to the fore in moving beyond analyses of the impact of institutional factors, and thus shedding light 
on other explanatory factors that may hold greater power in explaining differing approaches to employee voice in MNCs.

First, there seems to be a growing consensus on the influence of sector of operations. In this regard, MNCs in the manufacturing sector were more likely to adopt indirect voice approaches and were generally characterised by comparatively high levels of unionisation (Lamare et al., 2013; Marginson et al., 2010). In contrast, MNCs in the service sector were more likely to present hybrid or dualistic approaches combining direct and indirect employee voice methods. Digging more deeply, MNCs operating in financial/professional services, retail, wholesale, distribution and hospitality appear more likely to adopt minimalistic approaches to employee voice, i.e. adopt none or very few employee voice channels. However, where some form of employee voice is adopted by MNCs in these sectors, hybrid or dualistic approaches appear most common (Lavelle et al., 2010). Second, product diversification appears to be significant in explaining different approaches to employee voice, particularly in regard to double-breasting. MNCs characterised by a high level of product diversification are more likely to report union avoidance via double-breasting than MNCs with a more standardised product portfolio (Lamare et al., 2013). Lamare et al. (2013) show that double-breasting approaches are more common among diversified MNCs than among those with a single product. The interpretation here seems to infer that since product diversification entails a variety of production lines, and thus different employee groupings in each product line, this in turn results in the adoption of different employee voice approaches within such MNCs as management deal with each group differently according to their employment characteristics and union status. Third, MNCs that had recently acquired 'brownfield' sites, were more likely to combine hybrid approaches than MNCs which had opened greenfield sites or had not recently engaged in new investments (Gunnigle et al., 2009; Marginson et al., 2010).

\section{Subsidiary autonomy over industrial relations}

As we have seen above, scholarly inquiry on the latitude of subsidiary level management to articulate and develop their own employment practices is important for two primary reasons. First, exploration of subsidiary autonomy in industrial relations is a road comparatively less travelled (Collings, 2008). As Belizón et al. (2014: 6) note: 'despite the extensive literature examining subsidiary autonomy over a broad range of HR practices, there has been far less research with a specific focus on industrial relations matters'. Second, the extent of subsidiary autonomy over industrial relations is likely to be particularly sensitive to local institutional arrangements, probably more so than other employment practices such as performance management or training and development (Rosenzweig and Nohria, 1994). This makes comparative analysis across different national contexts particularly interesting. This gap in knowledge concerning variation in subsidiary autonomy has been identified by INTREPID scholars at a macro- and micro-level of analysis. 
Institutional (macro) factors shaping subsidiary autonomy over industrial relations. Drawing from past contributions on subsidiary autonomy over HRM practices, there appears to be a well-established pattern in US MNCs. Such firms normally allow limited scope for local managers in regard to HR practices (Almond and Ferner, 2006; Almond et al., 2005). In the industrial relations sphere, recent work using INTREPID data found that US MNCs afford subsidiaries located in Canada, Ireland, Spain and the UK lower levels of autonomy when compared to their European and Asian counterparts (Bélanger et al., 2013; Belizón et al., 2014; Ferner et al., 2011, 2013). Equally, host country effects remain an important factor in attempts to reveal how macro-settings in the country of operation impact on subsidiary autonomy in industrial relations (Almond and Ferner, 2006). MNC subsidiaries operating in more highly regulated labour market regimes such as Mediterranean countries (e.g. Spain) report higher levels of subsidiary autonomy than subsidiaries operating in more permissive regimes such as the UK, Ireland and Canada, where wider institutional leeway is granted to MNCs (Bélanger et al., 2013; Belizón et al., 2014; Ferner et al., 2011). Within more highly regulated regimes, this is normally attributed to the necessity to conform to specific local regulation and legal requirements (Marginson et al., 2010) while in more permissive systems MNCs can exercise greater strategic freedom to adopt practices originating in the country of origin or which are considered to be 'best practice' internationally (Belizón et al., 2014; Gunnigle et al., 2009). These findings are more or less in line with what one would expect, but the INTREPID contribution has not only been to demonstrate these patterns but also to show how they are mediated by organisational level factors.

Organisational (micro) factors shaping subsidiary autonomy over industrial relations. Much of the research effort of INTREPID scholars has focused on the impact of organisational factors over subsidiary autonomy in industrial relations. At this micro-level, substantial contributions have been made on two fronts: subsidiary characteristics and the deployment of international HR/IR structures.

Regarding subsidiary characteristics, we earlier noted how sector of operations constitutes a valuable explanatory factor in accounting for variation in management approaches to employee voice. First, we find that manufacturing MNCs are more likely to afford higher levels of autonomy (Belizón et al., 2014; Ferner et al., 2011). This is most likely related to the higher levels of unionisation in manufacturing and the related predisposition of such MNCs to rely on indirect employee voice approaches (Lamare et al., 2013). Second, mode of entry appears to impact on MNCs' capacity to implement managerial practices originated in the country of origin. MNCs that launch new operations through greenfield sites are unlikely to encounter pre-established workforce management traditions that might characterise brownfield sites (i.e. operations established via mergers or acquisitions). Consequently, entry through greenfield operations greatly enhance managerial capacity to follow corporate preference in industrial relations. Accordingly, INTREPID scholars have identified a pronounced tendency towards union 
avoidance in subsidiaries established at greenfield sites (Gunnigle et al., 2009). Third, a similar tendency was identified regarding the trajectory of new investments in the country of operation. INTREPID data provide evidence to suggest that establishment of new sites is significantly associated with lower levels of subsidiary autonomy over industrial relations practices (Belizón et al., 2014; Gunnigle et al., 2009). Arguably, the rationale behind this relationship may spring from the fact that new investments are generally undertaken under corporate guidelines and financial support, and thus are more exposed to central control (Tempel et al., 2006). Fourth, the extent of product or service diversification also has practical consequences for subsidiary autonomy. It seems that the greater the extent of diversification, the greater the level of subsidiary autonomy (Ferner et al., 2011). As argued in relation to employee voice above, diversification of products or services generally entails a more heterogeneous workforce (e.g. every product line could be served by a different profile of employee such as skilled, unskilled, etc.) which carries the need for MNCs to conform to both local regulatory requirements and the differing demands from different groups of employees. Diversified MNCs report, therefore, higher levels of subsidiary autonomy over industrial relations, arguably granted to allow local managers scope to deal with the needs of different groups of employees (Ferner et al., 2011; Pulignano et al., 2013).

A further micro-level factor that appears to be crucial in explaining variation in subsidiary autonomy is subsidiary capabilities. As Bélanger et al. (2013) observe: 'organizational capabilities are seen to be a key pillar for subsidiaries to gain space for decision-making within the MNC'. The influence of the power interplays between subsidiaries and headquarters (HQ) at a micro-level has been generally neglected in previous work, and consequently, studies of the effect of subsidiary capabilities on the level of subsidiary autonomy over industrial relations constitute an important step forward in attempts to move beyond institutions in explaining variation in industrial relations in MNCs. Prominent scholars posit that subsidiaries do not necessarily occupy weak and vulnerable positions but rather may garner power in their dealings with HQ (Ferner et al., 2012). Bélanger et al. (2013) identify two different subsidiary capabilities that account for variation in the level of subsidiary autonomy, namely, internal management capabilities and the extent of embeddedness of MNC subsidiaries in the local economy. The former

reflects the ability of local managers to develop positive relationships with the employees to foster innovation and to represent favourably the subsidiary within the broader structures of the firm. Such social resources are likely to promote investment in the subsidiary and secure more strategic mandates from headquarters (Bélanger et al., 2013: 325).

This work establishes a positive correlation between the strength of these subsidiary capabilities and higher levels of subsidiary autonomy in industrial relations. They also found that where MNCs were strongly embedded in the local economy, then subsidiaries are more likely to enjoy greater autonomy. Subsidiary embeddedness within the local economy was measured through the extent subsidiaries engage 
with their local institutional arena by establishing alliances with, for example, universities to undertake relevant research or by using different public services such as funding for new investments offered by local entities (Murray et al., 2014). Thus, the ability of actors at subsidiary level to generate competencies from their immediate context outside the firm shapes their relations with managers at higher levels within the firm.

Also within the micro-sphere, INTREPID researchers have investigated the impact of international HR/IR structures on subsidiary autonomy (Belizón et al., 2014; Ferner et al., 2011). While personal control exercised by expatriates from headquarters or third countries is related to low levels of subsidiary autonomy over industrial relations (Belizón et al., 2014), the deployment of various international HR structures seems to have no discernible impact on the extent of autonomy enjoyed by local managers in MNCs (Belizón et al., 2014; Ferner et al., 2011). In practical terms, this means that variations in the level of subsidiary autonomy in industrial relations appear detached from the use of international HR structures, such as the presence of an international committee acting as a policy-making body to develop and disseminate HRM practice across borders, the use of human resources information systems (HRIS), the incidence of direct and regular reporting from subsidiary to $\mathrm{HQ}$ on $\mathrm{HR} / \mathrm{IR}$ issues and the use of a shared service centre for HR. These international structures have proven to limit the level of subsidiary autonomy over other HR practices (Belizón et al., 2013; Ferner et al., 2011). However, IR practices seem to follow their own path. Thus, Ferner et al. (2011) argue that industrial relations practices, because of their local nature, are not as dependent on corporate strategies and structures as other areas of HR practice.

\section{Charting a future research agenda}

As illustrated above, considerable insights have been gleaned on the autonomy enjoyed by subsidiary level management in MNCs in their interaction with local unions and systems of collective representation. The factors shaping subsidiary autonomy at both institutional (macro) and organisational micro-level have been widely identified by the INTREPID network. Yet much remains to be done, not least the need for more extensive and comparative analyses of the power interplays or interaction between institutional- (home and host country effects) and firm-level organisational and structural factors impacting subsidiary level autonomy.

Of particular interest is how organisational (micro) level features mediate the extent of subsidiary level management discretion over employee representative engagement within MNCs. We have seen above reference to initial INTREPID work in this sphere. There is clearly room for some replication using the broader spectrum of 'wave two' countries which also provide scope for a regional focus. For example, it should be possible to compare these effects and measure their relative influence in MNC subsidiaries in the six European countries involved, namely, Belgium, Denmark, Ireland, Norway, Spain and the UK. In so doing, scholars 
might assess the effects of the above factors (independent variables) on trade union status and engagement. This would help advance understanding on how a wide range of factors influence both employee representation status and the extent of management discretion over collective representation.

As noted earlier, different types of MNCs operate in different institutional contexts and one way of categorising them is by country of origin. Again the addition of second wave countries provides the potential to explore variation amongst and within CME and LME market economies as identified by the VoC approach (Hall and Soskice, 2001). The Nordic countries, categorised as CMEs, and exemplified by Denmark and Norway in INTREPID, are arguably different from Germany, for instance, where the industrial relations system has a stronger legislative basis. Even within Nordic countries there may be differences between employment regimes, e.g. Denmark's use of more liberal approaches such as of 'flexicurity' (Gooderham et al., 2011; see also Gooderham et al., 2014 in current issue).

Future research could further profile the impact of sub-national governance systems, such as geographical regions (e.g. federal states), which often split jurisdiction over industrial relations issues, thus potentially inducing within-country variations in labour market regulation. In this regard, INTREPID now incorporates 'second wave' countries with a federal structure such as Belgium. Recent work in this area has highlighted the importance of the sub-national level in shaping management practices within MNCs (cf. Almond, 2011). However, most studies are qualitative and lack the capacity to assess the degree of variation (if any) on a sub-national level. Furthermore, a focus on within and across country variation will allow scholars to assess the extent to which factors that influence employee representation and local management discretion differ across diverse industrial relations systems. This is particularly relevant in the light of Hyman's (2009: 10) observation regarding the inadequate way in which scholars have responded so far to the dilemma of comparative research. As we have seen, comparative analysis in industrial relations is fraught with difficulty since national business and industrial relations systems generally differ in key respects, rendering each quite contextually bound and, in many respects, unique (cf. Crouch, 2005; Edwards et al., 2013). As Hyman (2009: 9-10) argues, reducing complexity and variety by elaborating different typologies or models and thereby engaging in 'typification' carries the disadvantage of reducing: '... diversity to a limited number of 'models' or ideal types and (supressing the)... more complex aspects of differentiation'. He also concedes that while this approach has the potential to effectively illustrate how economies can be shaped and operate according to different institutional logics, it also risks 'over-simplification' by identifying idealtypical country groupings based on particular characteristics, which may be shared to a differential degree by countries so categorised. This may prove a fruitful avenue for INTREPID scholars. In particular, because multiple determinants are at work, researchers interested in understanding the dynamics affecting the development of industrial relations practices within MNCs need to move away from over simplification of national economy types and embrace the 
complex interface of power interplay between macro-institutional and micro-organisational effects within MNCs.

Two particular lines of inquiry deal with different dimensions of context. First is the impact of sector, discussed above. Here INTREPID scholars might take up the challenge identified by Bechter et al. (2012: 185) that 'industrial relations vary across sectors as deeply as they do across countries'. This might be achieved by more in-depth analysis of sector and sub-sector variation. Earlier, we noted differences between manufacturing and service sector MNCs. However, this is arguably too crude a level of analysis and more specific sectoral categorisations such as European industrial activity classification (NACE codes) might be used in future work. This may need to be done on a comparative (cross-country) basis to garner adequate numbers of MNCs in each sectoral cell. A second important but somewhat problematic focus of future inquiry is the impact of the global financial crisis (GFC) on MNCs and industrial relations therein. A key challenge relates to variation in the timing of surveys. In the 'first wave' countries, surveys were undertaken between 2006 and 2008 while this work was undertaken in 'second wave' countries much later, mostly in the period 2010-2013. This is not unusual in comparative research of this nature (Edwards et al., 2013), especially in surveys such as INTREPID which address phenomena that do not change quickly. Work to date on the impact of the GFC has been largely qualitative in nature (cf. Gunnigle et al., 2013) and generally lacking in comparative focus, thus providing at least the possibility for greater quantitative analyses as might be undertaken using INTREPID data.

Of course, the INTREPID data and scholarship thereon are not without limitations, as alluded to above. ${ }^{3}$ While this work facilitates advanced analysis of practice and behaviour in MNCs in differing contexts, it cannot shed substantive light on issues of process, effectively, the means by which MNCs deploy certain practices and their underlying motives. Case study based methodologies remain the favoured way of investigating such phenomena. Equally this work captures practice at a particular point in time and is therefore unable to provide a longitudinal perspective which might chart the development and evolution of employment practice in MNCs. The project also largely relies on survey data from developed economies and it would be beneficial if, in future, we might witness greater participation from emerging economies.

\section{Declaration of conflicting interests}

The authors declare that there is no conflict of interest.

\section{Funding}

The project was supported by the Argentinian Ministry of Labour; the Australian Research Council; Canada's Social Sciences and Humanities Research Council, the Fonds québécois de recherché sur la société et la culture (Équipes and Regroupements stratégiques), the Canada Research Chair on Globalization and Work, the Interuniversity Research 
Centre on Globalization and Work (CRIMT); The Danish Council for Independent Research (Social Sciences) (FSE); the European Commission's International Research Staff Exchange Scheme (FP7 IRSES-GA-2008-230854-INTREPID); Ireland's Labour Relations Commission and the Irish Research Council for the Humanities and Social Sciences; the Mexican National Council for Technology and Science (CONACYT, project no. 55080); the Research Council of Norway; Spain's Ministries of Education and Science (Ref. SEJ2007-03096, Award 01/0010/2006) and Science and Innovation (Ref: ECO200910287), the Directorate-General for Scientific Investigation of the Madrid region (Award 06/ 0009/2000), the BBVA Foundation (Ref. 216/06), the Autonomous University of Madrid/ Banco Santander (Ref: CEAL-AL/2011-28), IESE Business School and the United Kingdom's Economic and Social Research Council (Awards RES-000-23-0305 and RES062-23-2080).

\section{Notes}

1. INTREPID comprises a network of international scholars involved in parallel surveys of employment practices in multinational companies (MNCs) across different national contexts. These surveys were initially conducted in Canada, Ireland, Spain and the UK and were the most representative investigations of their kind in these countries. Subsequent surveys were conducted in 'second wave' countries, namely Argentina, Australia, Belgium, Denmark, Mexico and Norway. For a detailed overview of the methodology employed see Edwards et al. (2013), and for additional information on each country see Novick et al. (2011) on Argentina; McDonnell et al. (2011) on Australia; Minbaeva and Navrbjerg (2011) on Denmark; McDonnell et al. (2007) and Lavelle et al. (2009) on Ireland; Carrillo and Gomis (2014) on Mexico; Quintanilla et al. (2010) on Spain; Steen (2010) on Norway and Edwards et al. (2007) on the UK. Data collection in Belgium is near completion.

2. Face to face interviews were not conducted in Canada, Denmark and Norway where respondents were required to complete the questionnaire in either hard copy or on-line. This was supplemented by a small number of qualitative interviews (cf. Edwards et al. 2013 and relevant country reports).

3. Greater detail on the methodology employed and limitations thereof is provided in a Special Issue of Industrial and Labor Relations Review based on the INTREPID project published in Spring 2013 (volume 66, number 3) and entitled 'Cross-National Perspectives on Multinational Companies and Employment Relations'.

\section{References}

Almond F and Ferner A (2006) American Multinationals in Europe: Managing Employment Relations Across National Borders. Oxford: Oxford University Press.

Almond P (2011) The sub-national embeddedness of international HRM. Human Relations 64(4): 531-551.

Almond P, Edwards T, Colling T, et al. (2005) Unravelling home and host country effects, an investigation of the HR policies of an American multinational in four European countries. Industrial Relations: A Journal of Economy and Society 44(2): 276-307.

Arrowsmith J and Marginson P (2006) The European cross-border dimension to collective bargaining in multi-national companies. European Journal of Industrial Relations 12(3): 245-266. 
Bechter B, Brandl B and Meardi G (2012) Sector or countries? Typologies and levels of analysis in comparative industrial relations. European Journal of Industrial Relations 18(3): 185-202.

Bélanger J, Levesque C, Jalette P, et al. (2013) Discretion in employment relations policy among foreign-controlled multinationals in Canada. Human Relations 66(3): 307-332.

Belizón MJ, Gunnigle P and Morley M (2013) Determinants of central control and subsidiary autonomy in HRM: The case of foreign-owned multinational companies in Spain. Human Resource Management Journal 23(3): 262-278.

Belizón MJ, Gunnigle P, Morley M, et al. (2014) Subsidiary autonomy over industrial relations in Ireland and Spain. European Journal of Industrial Relations. DOI: 10.1177/ 0959680113517199.

Boxall P and Purcell J (2003) Strategy and Human Resource Management. London: Palgrave. Carrillo J and Gomis R (2014) Las Multinacionales En Dato: Empleo, Recursos Humanos E Innovación. Tijuana: El Colegio de la Frontera Norte (in press).

Collings DG (2008) Multinational corporations and industrial relations research: A road less travelled. International Journal of Management Reviews 10(2): 173-193.

Collinson S and Rugman A (2010) Case selection biases in management research: The implications for international business studies. European Journal of International Management 4(5): 441-463.

Crouch C (2005) Capitalist Diversity and Change. Oxford: Oxford University Press.

Edwards P, Edwards T, Ferner A, et al. (2007) Employment practices of MNCs in organisational context: A large-scale survey. Report of the main survey. Available at: http:// www2.warwick.ac.uk/fac/soc/wbs/projects/mncemployment/conference_papers/full_ report_july.pdf (accessed 2 December 2014).

Edwards T, Jalette P and Tregaskis O (2012) To what extent is there a regional logic in the management of labour in multinational companies? International Journal of Human Resource Management 23(12): 2468-2490.

Edwards T, Marginson P and Ferner A (2013) Multinational companies in cross-national context: Integration, differentiation, and the interactions between MNCs and nation states. Industrial and Labor Relations Review 66(3): 547-587.

Ferner A, Almond P and Colling T (2005) Institutional theory and the cross-national transfer of employment policy: The case of 'workforce diversity' in US multinationals. Journal of International Business Studies 36(3): 304-321.

Ferner A and Quintanilla J (1998) Multinationals, national systems and HRM: The enduring influence of national identity or a process of 'Anglo-Saxonization'? International Journal of Human Resource Management 9(4): 710-731.

Ferner A, Tregaskis O, Edwards P, et al. (2011) HRM structures and subsidiary discretion in foreign multinationals in the UK. International Journal of Human Resource Management 22(3): 483-509.

Ferner A and Varul MZ (1999) The German Way: German MNCs and Human Resource Management. London: Anglo-German Foundation.

Ferner AM, Edwards T and Tempel A (2012) Power, institutions and the cross-national transfer of employment practices in multinationals. Human Relations 65(2): 163-187.

Freeman RB and Medoff JL (1984) What Do Unions Do? New York: Basic Books.

Geary J and Roche WK (2001) Multinationals and human resource practices in Ireland: A rejection of the "new conformance thesis". International Journal of Human Resource Management 12(1): 109-127. 
Gooderham P, Navrbjerg SE, Olsen KM, et al. (2011) Arbeidslivsregimer i Danmark og Norge - går de hver sin vei? (Employment regimes in Denmark and Norway: A parting of the ways?). Tidsskrift for Arbejdsliv 13(3): 30-44.

Gooderham P, Navrbjerg SE, Olsen KM, et al. (2014) The labor market regimes of Denmark and Norway - One Nordic model? Journal of Industrial Relations. DOI: $10.1177 / 0022185614534103$.

Gunnigle P (1995) Collectivism and the management of industrial relations in greenfield sites. Human Resource Management Journal 5(3): 24-40.

Gunnigle P, Collings D and Morley M (2005) Exploring the dynamics of industrial relations in US multinationals: Evidence from the Republic of Ireland. Industrial Relations Journal 36(3): 241-256.

Gunnigle P, Lavelle J and McDonnell A (2009) Subtle but deadly? Union avoidance through 'double breasting' among multinational companies. Advances in Industrial and Labor Relations 16: 51-74.

Gunnigle P, Lavelle J and Monaghan S (2013) Weathering the storm? Multinational companies and human resource management through the global financial crisis. International Journal of Manpower 34(3): 214-231.

Hall PA and Soskice D (eds) (2001) Varieties of Capitalism: The Institutional Foundations of Comparative Advantage. Oxford: Oxford University Press.

Hyman R (2009) How can we study industrial relations comparatively? Bulletin of Comparative Labour Relations 70: 3-23.

Jacoby SM (1997) Modern Manors. Welfare Capitalism Since the New Deal. Princeton, NJ: Princeton University Press.

Lamare R, Gunnigle P, Marginson P, et al. (2013) Union status and double-breasting at multinational companies in three liberal market economies. Industrial and Labor Relations Review 66(3): 696-722.

Lavelle J (2008) Charting the contours of union recognition in foreign-owned MNCs: Survey evidence from the Republic of Ireland. Irish Journal of Management 29(1): 45-63.

Lavelle J, Gunnigle P and McDonnell A (2010) Patterning employee voice in multinational companies. Human Relations 63(3): 395-418.

Lepak D and Snell S (1999) The human resource architecture: Towards a theory of human capital allocation and development. Academy of Management Review 24(1): 31-48.

McDonnell A, Lavelle J and Gunnigle P (2014) Human resource management in multinational enterprises: Evidence from a late industrialising economy. Management International Review. DOI: 10.1007/s11575-014-0202-y.

McDonnell A, Lavelle J, Gunnigle P, et al. (2007) Management research on multinational corporations: A methodological critique. Economic and Social Review 38(2): 235-258.

McDonnell A, Russell H, Sablok G, et al. (2011) Report: A profile of human resource management in multinational enterprises operating in Australia. Available from:http:// ahri.clients.squiz.net/resources/reports-and-white-papers/?a=7575 (accessed 2 December 2014).

Marginson P, Edwards P, Edwards T, et al. (2010) Employee representation and consultative voice in multinational companies operating in Britain. British Journal of Industrial Relations 48(1): 151-180.

Marginson P, Hall M, Hoffmann A, et al. (2004) The impact of European works councils on management decision-making in UK- and US-based multinationals. British Journal of Industrial Relations 40(2): 209-234. 
Marginson P and Meardi G (2009) Multinational Companies and Collective Bargaining. Dublin: European Foundation for the Improvement of Living and Working Conditions.

Marginson P, Lavelle J, Quintanilla J, et al. (2013) Variation in approaches to European works councils in multinational companies. Industrial and Labor Relations Review 66(3): 618-644.

Meardi G, Marginson P, Fichter M, et al. (2009) Varieties of multinationals. Adapting employment practices in Central Eastern Europe. Industrial Relations 48(3): 489-512.

Minbaeva D and Navrbjerg SE (2011) Employment practices of multinational companies in Denmark. Result Report SMG, Copenhagen Business School and FAOS, University of Copenhagen.

Murray G, Jalette P, Bélanger J, et al. (2014) The 'hollowing out' of the national subsidiary in multinational companies: Is it happening, does it matter, what are the strategic consequences? Transfer: European Review of Labour and Research. DOI: 10.1177/ 1024258914525564.

Novick M, Palomino H and Gurrera MS (2011) Multinacionales en la Argentina. Buenos Aires: Programa Naciones Unidas para el Desarrollo (PNUD), Ministerio de Trabajo, Empleo y Seguridad.

Pulignano V, Doerflinger N and De Franceschi F (2013) Flexibility and security within European labour markets: The role of local bargaining and the varieties of 'trade-offs' within multinationals. In: Paper presented at 10th ILERA, Amsterdam, The Netherlands, 20-22 June 2013.

Quintanilla J, Belizón MJ, Sánchez-Mangas R, et al. (2010) Employment practices of multinational companies in Spain [Survey Report]. Madrid: IESE.

Rosenzweig P and Nohria N (1994) Influences on human resource management practices in multinational corporations. Journal of International Business Studies 25(2): 229-251.

Royle T (1998) Avoidance strategies and the German system of co-determination. International Journal of Human Resource Management 9(6): 1026-1047.

Royle T (ed.) (2000) Working for McDonald's in Europe: The Unequal Struggle. London: Routledge.

Royle T (2006) The dominance effect? Multinational corporations in the Italian quick-food service sector. British Journal of Industrial Relations 44(4): 757-779.

Sablok G, Bartram T, Stanton P, et al. (2013) The impact of union presence and strategic human resource management on employee voice in multinational enterprises in Australia. Journal of Industrial Relations 55(4): 621-639.

Steen CR (2010) Survey av HR praksiser $i$ multinasjonale selskaper $i$ Norge. Presentasjonavførsteresultater. Workshop Presentation, Solstrand, Bergen.

Taylor S, Beechler S and Napier N (1996) Toward an integrative model of strategic international human resource management. Academy of Management Review 21(4): 959-985.

Tempel A, Edwards T, Ferner A, et al. (2006) Subsidiary responses to institutional duality: Collective representation practices of US multinationals in Britain and Germany. Human Relations 59(11): 1543-1570.

Waddington J (2010) European Works Councils and Industrial Relations. London: Routledge.

Whitley R (1999) Divergent Capitalisms: The Social Structuring and Change of Business Systems. Oxford: Oxford University Press.

Whitley R (2001) How and why are international firms different? The consequences of crossborder managerial coordination for firm characteristics and behaviour. In: Morgan G, 
Kristensen PH and Whitley R (eds) The Multinational Firm: Organizing Across Institutional and National Divides. Oxford: Oxford University Press, pp. 27-68.

Williams K and Geppert M (2011) Bargained globalisation: Employment relations providing robust "tool kits" for socio-political strategizing in MNCs in Germany. In: Dörrenbächer C and Geppert M (eds) Politics and Power in the Multinational Corporation. Cambridge: Cambridge University Press.

\section{Biographical notes}

Patrick Gunnigle is Professor of Business Studies at the University of Limerick and Visiting Professor in Industrial Sociology at Rhodes University. His research has been published in leading journals such the British Journal of Industrial Relations, Industrial and Labor Relations Review and Industrial Relations (US).

Valeria Pulignano is Professor in Labour Sociology and Industrial Relations at the Katholieke Universiteit of Leuven (Belgium) and coordinator of the Center for Sociological Research (CESO). She has published, among others The Transformation of Employment Relations in Europe (Routledge, 2014).

Tony Edwards is Professor in Comparative HRM at Kings College London. His research centres on the management of workforces in multinational companies and has been published in many of the leading journals in his field.

María Jesús Belizón is a doctoral scholar at the Kemmy Business School, University of Limerick, Ireland. Her research focuses on international human resource management in multinational companies. Specifically, she has published work on the extent and determinants of subsidiary autonomy over HRM and industrial relations in multinational subsidiaries.

Steen E Navrbjerg is Associate Professor at the Employment Relations Research Centre (FAOS), University of Copenhagen (Denmark). His research has been published in journals such as The International Journal of Human Resource Management and Economic and Industrial Democracy.

Karen M Olsen is Professor in Human Resource Management at Norwegian School of Economics (NHH), Bergen. Her research has been published in leading journals such as Human Resource Management (US), Work, Employment \& Society and the European Journal of Industrial Relations.

Lourdes Susaeta is Associate Professor at the University Complutense, Madrid and Associate Researcher at IESE Business School. Her research has been published in journals such as Industrial \& Labor Relations Review and Cross Cultural Management. 